\title{
Appraisal of the problems affecting microfinance banks in emerging economies and the mitigating factors: Nigeria's experience
}

\author{
Israel S. Akinadewo \\ Ebenezer Y. Akinkoye \\ O. O. Olasanmi
}

Department of Management \& Accounting

Obafemi Awolowo University, Ile-Ife, Osun State, Nigeria

\begin{abstract}
Keywords
Entrepreneurs, Funding, Microfinance banks, Mitigating factors, MSMEs.
\end{abstract}

\begin{abstract}
This study appraised the problems of microfinance banks in Nigeria and evaluated the mitigating factors. Survey research design through the administration of structured questionnaire was adopted for data collection. The targeted population was 250 microfinance banks operators and micro, small and medium entrepreneurs. The respondents validly returned 223 copies of the questionnaire. Descriptive statistics like table, mean, standard deviation and percentages were used for data analyses. The findings revealed that high operating and financial expenses (99.6\%); low revenue base (99.6\%); lack of effective corporate governance $(99.6 \%)$; lack of standard and uniformity in financial transactions (99.6\%); insiders' abuse (99.6\%); and ineffective monitoring of the allocated funds to ensure the utilisation as intended (99.6\%) are highly critical among the twenty identified problem confronting microfinance banks in Nigeria. The results also showed that majority of the respondents believed that among the twenty identified mitigating factors to the problems of MFBs in Nigeria, timely preparation of financial statements (99.6\%); adoption of cost efficiency mechanism $(99.6 \%)$; investing more on information technology for enhancement of operations (99.6\%); standardisation of the quality, experience and qualifications of management of microfinance (99.6\%); and effective background check of staff and customers are the most important. The study therefore recommends the need for government to evaluate these findings and timely deploy the mitigating factors for the enhancement of the growth of microfinance banks in Nigeria.
\end{abstract}

\section{Introduction}

In recent years, scholars have showed increased interest in microfinance banks. Historically, the efficient administration of these non-conventional banks is considered a key factor to the growth of Micro, Small and Medium Enterprises (MSMEs). This is achieved through the granting of credits. Evidence suggests that most of the successful economies have attained this through MSMEs (Bakare, 2019). In Nigeria, microfinance bank was established and designed as specialised institution to promote grassroots banking in attaining rapid rural and entrepreneurial development (Obadeyi, 2015). It also emerged in the nation's economic fora as a noble substitute for informal credit system being in operation in rural areas, and to serve as an effective instrument for poverty reduction among the economically deficient and vulnerable people (Nwude and Anyalechi, 2018; Taiwo et al., 2016; Nwachukwu et al., 2017). Consequent to this, the expected growth of the micro and medium businesses would arguably be achievable through a strong financial base and efficiently managed Microfinance Banks (MFBs). Despite the expected positive impact of these banks to MSMEs in Nigeria, there has been sceptical belief that this has been attained. This doubtful position was reinforced in the literature of the operational problems and other issues that fundamentally affect the development of microfinance banks in Nigeria.

According to Akande and Yinus (2015), microfinance industry is challenged in several ways. These include the need to extend its products and services to the greater number of the poor; high operating cost; repayment problem; inadequate experienced credit staff; lack of refinancing facilities, etc (Akande and Yinus, 2015; Alalade et al., 2013). In furtherance of this, Ehigiamusoe (2005), cited by Alalade et al. (2013) argued that it is only efficient institutions that can reach large number of people for substantial impact on poverty. Questions have also been raised about the survival of MFBs amidst the problems hindering the efficiency of their activities. Regarding this, it is also uncertain whether microfinance has 
impacted in the reduction of poverty for economic growth (Moruf, 2013). Scholars have also argued that to achieve a sustainable performance, the banks should devise the necessary strategies to combat the problems confronting them (Alalade et al., 2013). To substantiate for the need to proffer solution to the hindering factors, Reusser and Stebler (1997) opined that every word problem has a solution. Thus, it is then imperative to identify the solution to the identified problems of microfinance banks.

Studies have recognised the problems of microfinance banks though, but there is still paucity of research on a systematic identification of specific problems and the associated mitigating factors. Most of these studies have also been limited to a small number of problems and have failed to provide robust solutions to these. The aim of this paper therefore is to identify twenty problems and twenty mitigating factors, and to empirically appraise these from the perception of the stakeholders.

\section{Review of related literature and theoretical framework}

Microfinance banks in Nigeria were established and regulated by the appropriate authorities to primarily bridge the lacuna between small businesses and accessibility to funding. It is one of the measures of strategic approach to the enhancement of capacity building, in human resources and industrial development of a social environment (Obasi et al., 2014). Regarding this, Ashamu (2014) argued that the MFBs were established to be financially sound, stable, self-sustaining and integrate effectively in the communities of their operations. Obokoh et al. (2016) argued in line with Ashamu (2014) that the objective for the ushering of MFBs into the financial arena in Nigeria was to make them vehicles for socialeconomic growth and rural transformation. The scholars further opined that the intent was to reduce the burden of high interest rates and other financial charges hitherto charged by conventional banks, and to provide financial, advisory, technical, and managerial supports for small scale enterprises. Dutse et al. (2013) also believed that the primary objective for the establishment of MFBs is the provision of financial services to entrepreneurs of MSMEs in improving the socio-economic condition and their incomegeneration activities. Expectedly, these assertions should translate to rapid development for small scale businesses entrepreneurs, but evidence from the literature suggests otherwise.

Regarding this, Andabai and Jessie (2018) believed that the activities of microfinance banks have not significantly contributed to the growth of small-scale businesses in Nigeria. To these scholars, premium should be placed on ethical and professional conducts by ensuring that soft loans are given to credible and promising entrepreneurs. The position of Andabai and Jessie (2018) is slightly in agreement with the study of Aliu et al. (2015). While Andabai and Jessie had concern over ethical and professional conducts, Aliu et al. (2015) argued that over $70 \%$ of small-scale businesses still faced difficulties in accessing credit facilities from microfinance banks. Contributing to this, Sussan and Obamuyi (2018) agreed with Andabai and Jessie (2018) and Aliu et al. (2015) that microfinance bank has not significantly impacted on the development of entrepreneurship in Nigeria. In the study conducted by Sussan and Obamuyi (2018), it was argued that there are problems militating against the effective financing of entrepreneurs by the microfinance banks. According to these authors, those problems hinder the attainment of the objectives of MFBs in Nigeria. Sussan and Obamuyi (2018) further postulated that the microfinance banks still have a lot to do to substantially increase the funding of small-scale businesses for effective and positive impact on economic growth. Obasi et al. (2014), while agreeing with this, opined that microfinance industry has not really distinguished itself from the practices of other community banks in terms of credit to enhance the growth of small-scale entrepreneurs.

In contrast, Murad and Idewele (2017) opined that in the short run, microfinance loans will positively and significantly improve economic growth in Nigeria. Murad and Idewele (2017) further postulated that in the long run, microfinance do not have a significant impact on economic growth. Ailemen et al. (2016) however argued that the challenges facing MFBs are global and are the causes for their inability to realistically achieve their objectives.

According to Ailemen et al. (2016), these challenges include - consideration for cost management; efforts to reach increasingly poorer and more remote people; the need to scale up the quality of MFBs service deliveries; optimisation of technology; infrastructure deficiency; low level of leveraging crossborder remittances of funds and other remote rural transfers; and difficulty in reaching the expected beneficiaries of MFBs services in the remote areas. In the review of literatures, Abubakar et al. (2015) argued that the quantum of problems hindering the activities of MFBs are - problems of regulation, 
inaccessibility of services to the poor, capital inadequacy, demand, and supply gap in the provision of micro credit and micro saving, high transaction cost, non-availability of documentary evidence, and problem of repayment tracking. The study of Abubakar et al. (2015), which was not empirically based, suggests government intervention through participation in the area of infrastructure, employment of the right caliber of staff, products diversification, associating with the right clients with high sense of integrity as some of the measures needed to tackle the challenges of MFBs.

Deviating from the issues affecting MFBs, Ademoh and Zivkovic (2017) believed that the problems should rather be from the expected beneficiaries of the services. These scholars asserted that some smallscale entrepreneurs hardly approach MFBs for loans due to lack of collateral, ignorance of the existence of these banks, and the inability to meet up with high interest rate. Ademoh and Zivkovic (2017) further opined that businesses are ignorant of the existence of MFBs due to the latter's lack of advertising their services and the small business entrepreneurs lack the understanding of the significance of these banks. What is striking in this paper that also differentiates it from the reviewed studies is the empirical identification of the problems of MFBs in Nigeria and the relevant solution thereof.

To theoretically explain the focus of this study, it is globally acknowledged that funding is key to the survival and growth of businesses. Khan (2020) meanwhile, states that elementary corporate finance theory believes that investment project should be undertaken when the net present value is positive. Despite this, availability of finance is a critical factor for consideration in any planned project. While the reviewed studies showed that the primary objective of MFBs is to support the activities of MSMEs, the challenges faced by the former have become the interruptive factor against effective support for the financial and other needs of the latter. Thus, it could be deduced that whenever MFBs face challenges, the MSMEs suffer. This conforms with the elementary accounting principle of double entry (every debit must have a corresponding credit), the economics theory of demand and supply, and the accounting, as well as the normal life principle of - where there is a giver, then there will be a receiver. It then implies that where the expected giver is lacking, then the expected receiver will be waiting in vain. This position explains the justification for this study to also proffer solution to the identified challenges facing MFBs in Nigeria.

\section{Methodology}

This study adopted research design method. Self-administered and structured questionnaires were administered on respondents. The targeted population and the sample size were 250 microfinance operators and micro, small and medium entrepreneurs in Lagos State, Nigeria. The respondents were purposively chosen from Lagos State, being the commercial hub of Nigeria and has the largest concentration of microfinance banks and MSMEs in Nigeria. Meanwhile, only $223(89.2 \%)$ respondents validly returned the questionnaire. Descriptive statistics were utilised to analyse data.

\section{Data presentation, analysis, and discussion of findings}

This section presents and discusses the results of the valid responses received from the respondents. These were perceptually on the problems affecting microfinance banks in Nigeria and the likely factors for mitigation. This study used the 5-points Likert scale to enable the respondents select the relevant columns divided into strongly agree (SA - 5), agree (A - 4), undecided ( $\mathrm{C}-3)$, disagree (D - 2), and strongly disagree (SD - 1). The perception of the respondents, to empirically identify twenty (20) problems of microfinance banks in Nigeria and twenty (20) mitigating factors were appraised using tables, percentage, mean and standard deviation. To make the discussion of findings much easier, the responses under SD and $\mathrm{D}$ were grouped under a column, the $\mathrm{U}$ scale has a separate column, and A and SA, grouped in same column.

Table 1 shows the descriptive results of the perception of the stakeholders on the problems that have hindered the growth of microfinance banks in Nigeria. The structured problems identified and sent through questionnaire to respondents for appraisal are - high operating and financial expenses; low revenue base; lack of effective corporate governance; insufficient expertise; inadequate start-up capital and poor funding; ineffectiveness of policy framework and regulatory monitoring; inability to adequately extend funding to the larger number of poor citizens and small businesses; high level of non-performing loans due to poor collateral; inefficient management; low funding of real sector like agriculture and manufacturing; diversion of funds; inconsistencies of government policies; lack of standard and 
uniformity in financial transactions; insufficient publicity and awareness at the grassroots; insiders' abuse; inadequate business opportunities; low literacy of the expected target, leading to difficulty in effective communication; poor data base of the expected fund target; fraudulent practices and corruption in the industry; and ineffective monitoring of the allocated funds to ensure the utilisation as intended.

Interestingly, all the identified problems in table 1, were appraised and agreed with by the majority of the respondents as hindrances to the growth of microfinance banks in Nigeria, but with slightly different ratings ranging from $97.8 \%$ to $99.6 \%$. This implies that these problems are hugely responsible for the inability of Microfinance banks in Nigeria to achieve the purpose for the establishment. The respondents, however, appraised: high operating and financial expenses (99.6\%); low revenue base $(99.6 \%)$; lack of effective corporate governance $(99.6 \%)$; lack of standard and uniformity in financial transactions (99.6\%); insiders' abuse (99.6\%); and ineffective monitoring of the allocated funds to ensure the utilisation as intended $(99.6 \%)$ as the most critical of the problems.

Table 1: Problems affecting microfinance banks in Nigeria

\begin{tabular}{|c|c|c|c|c|c|c|c|c|c|}
\hline Factors & $\mathrm{N}$ & $\mathrm{SD}+\mathrm{D}$ & $\mathrm{U}$ & $A+S A$ & Total & Min. & Max. & Mean & $\begin{array}{l}\text { Std. } \\
\text { Dev. }\end{array}$ \\
\hline $\begin{array}{l}\text { High operating and } \\
\text { financial expenses }\end{array}$ & 223 & $1(0.4 \%)$ & $0(0.0 \%)$ & $222(99.6 \%)$ & $223(100 \%)$ & 1.00 & 5.00 & 4.7265 & .50365 \\
\hline Low revenue base & 223 & $0(0,0 \%)$ & $1(0.4 \%)$ & $222(99.6 \%)$ & $223(100 \%)$ & 3.00 & 5.00 & 4.6502 & .48731 \\
\hline $\begin{array}{l}\text { Lack of effective corporate } \\
\text { governance }\end{array}$ & 223 & $0.0(0.0 \%)$ & $1(0.4 \%)$ & $222(99.6 \%)$ & $223(100 \%)$ & 3.00 & 5.00 & 4.4933 & .50999 \\
\hline Insufficient expertise & 223 & $0(0.0 \%)$ & $2(0.9 \%)$ & $221(99.1 \%)$ & $223(100 \%)$ & 3.00 & 5.00 & 4.4260 & .51346 \\
\hline $\begin{array}{l}\text { Inadequate start-up capital } \\
\text { and poor funding }\end{array}$ & 223 & $1(0.4 \%)$ & $2(0.9 \%)$ & $220(98.7 \%)$ & $223(100 \%)$ & 2.00 & 5.00 & 4.4439 & .54131 \\
\hline $\begin{array}{l}\text { Ineffectiveness of policy } \\
\text { framework and regulatory } \\
\text { monitoring }\end{array}$ & 223 & $2(0.9 \%)$ & $1(0.4 \%)$ & $220(98.7 \%)$ & $223(100 \%)$ & 2.00 & 5.00 & 4.5695 & .55618 \\
\hline $\begin{array}{l}\text { Inability to adequately } \\
\text { extend funding to the } \\
\text { larger number of poor } \\
\text { citizens and small } \\
\text { businesses }\end{array}$ & 223 & $2(0.9 \%)$ & $1(0.4 \%)$ & $220(98.7 \%)$ & $223(100 \%)$ & 2.00 & 5.00 & 4.5471 & .55854 \\
\hline $\begin{array}{l}\text { High level of non- } \\
\text { performing loans due to } \\
\text { poor collateral }\end{array}$ & 223 & $2(0.9 \%)$ & $1(0.4 \%)$ & $220(98.7 \%)$ & $223(100 \%)$ & 2.00 & 5.00 & 4.6188 & .54773 \\
\hline Inefficient management & 223 & $1(0.4 \%)$ & $4(1.8 \%)$ & $218(97.8 \%)$ & $223(100 \%)$ & 2.00 & 5.00 & 4.5561 & .55770 \\
\hline $\begin{array}{l}\text { Low funding of real sector } \\
\text { like agriculture and } \\
\text { manufacturing }\end{array}$ & 223 & $1(0.4 \%)$ & $4(1.8 \%)$ & $218(97.8 \%)$ & $223(100 \%)$ & 2.00 & 5.00 & 4.6188 & .54773 \\
\hline Diversion of funds & 223 & $1(0.4 \%)$ & $4(1.8 \%)$ & $218(97.8 \%)$ & $223(100 \%)$ & 1.00 & 5.00 & 4.5740 & .57941 \\
\hline $\begin{array}{l}\text { Inconsistencies of } \\
\text { government policies }\end{array}$ & 223 & $2(0.9 \%)$ & $3(1.3 \%)$ & $218(97.8 \%)$ & $223(100 \%)$ & 1.00 & 5.00 & 4.5874 & .59292 \\
\hline $\begin{array}{l}\text { Lack of standard and } \\
\text { uniformity in financial } \\
\text { transactions }\end{array}$ & 223 & $0(0.0 \%)$ & $1(0.4 \%)$ & $222(99.6 \%)$ & $223(100 \%)$ & 2.00 & 5.00 & 4.5785 & .52150 \\
\hline $\begin{array}{l}\text { Insufficient publicity and } \\
\text { awareness at the } \\
\text { grassroots }\end{array}$ & 223 & $1(0.4 \%)$ & $1(0.4 \%)$ & $221(99.2 \%)$ & $223(100 \%)$ & 2.00 & 5.00 & 4.6637 & .51015 \\
\hline Insiders' abuse & 223 & $1(0.4 \%)$ & $0(0.0 \%)$ & $222(99.6 \%)$ & $223(100 \%)$ & 2.00 & 5.00 & 4.6009 & .51762 \\
\hline $\begin{array}{l}\text { Inadequate business } \\
\text { opportunities }\end{array}$ & 223 & $2(0.9 \%)$ & $0(0.0 \%)$ & $221(99.1 \%)$ & $223(100 \%)$ & 2.00 & 5.00 & 4.6054 & .54224 \\
\hline $\begin{array}{l}\text { The low-level literacy of } \\
\text { the expected targets, } \\
\text { leading to difficulty in } \\
\text { effective communication }\end{array}$ & 223 & $4(1.8 \%)$ & $1(0.4 \%)$ & $218(97.8 \%)$ & $223(100 \%)$ & 2.00 & 5.00 & 4.5426 & .60533 \\
\hline Poor data base of the & 223 & $3(1.4 \%)$ & 1 & 219 & $223(100 \%)$ & 2.00 & 5.00 & 4.5964 & .57609 \\
\hline
\end{tabular}




\begin{tabular}{|c|c|c|c|c|c|c|c|c|c|}
\hline expected funds target & & & $(0.4 \%)$ & $(98.2 \%)$ & & & & & \\
\hline $\begin{array}{l}\text { Fraudulent practices and } \\
\text { corruption in the industry }\end{array}$ & 223 & $1(0.4 \%)$ & $\begin{array}{l}3 \\
(1.4 \%)\end{array}$ & $219(98.2 \%)$ & $223(100 \%)$ & 2.00 & 5.00 & 4.5112 & .55232 \\
\hline $\begin{array}{l}\text { Ineffective monitoring of } \\
\text { the allocated funds to } \\
\text { ensure the utilisation as } \\
\text { intended }\end{array}$ & 223 & $1(0.4 \%)$ & $\begin{array}{l}0 \\
(0.0 \%)\end{array}$ & $\begin{array}{l}222 \\
(99.6 \%)\end{array}$ & $223(100 \%)$ & 2.00 & 5.00 & 4.7175 & .48025 \\
\hline Valid N (listwise) & 223 & & & & & & & & \\
\hline
\end{tabular}

Source: Authors' field work (2020)

Table 2 explains the rating of the factors that could mitigate the problems of microfinance banks in Nigeria. The factors are: timely preparation of financial statements; adoption of cost efficiency mechanism; development of sound microfinance practice with sustainable regulatory framework; timely prosecution of fraudsters; introduction of more effective internal control system; investing more on information technology for enhancement of operations; improvement on the know-your-customers (KYC) information guidelines; standardisation of the quality, experience and qualifications of management of microfinance banks; effective background check of staff and customers; timely investigation of any undercapitalisation below the lower limit; the need for government and other stakeholders to inculcate sound banking culture in management and customers; increase in revenue base through products diversification; creation of more awareness to the poor and small businesses; the need for more workshops and training programs for microfinance staff; building of investors' confidence through government participation in areas like provisions of security and infrastructure; the need for a more proactive corporate governance framework; government should be more consistent with policies; appropriate tax incentives for MFBs to enhance business growth; government should establish a more reliable data collection of small businesses in need of funds; and the need for effective monitoring of how loans given to customers are utilised through appropriate management-customer forum.

The results in table 2 showed that majority of the respondents agreed that these mitigating factors, when deployed, will mitigate the problems confronting microfinance growth in Nigeria. This is affirmed with the sum of the percentage for agreed (A) and strongly agree (SA) ranging from $97.4 \%$ to $99.6 \%$. The respondents however opinionated that: timely preparation of financial statements (99.6\%); adoption of cost efficiency mechanism (99.6\%); investing more on information technology for enhancement of operations (99.6\%); standardisation of the quality, experience, and qualifications of management of microfinance $(99.6 \%)$; and effective background check of staff and customers are the most important among the mitigating factors.

Table 2: Mitigating factors of the problems affecting microfinance banks in Nigeria

\begin{tabular}{|c|c|c|c|c|c|c|c|c|c|}
\hline Factors & $\mathrm{N}$ & $\begin{array}{l}\text { SD }+ \\
\mathrm{D}\end{array}$ & $\mathrm{U}$ & $\mathrm{A}+\mathrm{SA}$ & Total & Min. & Max. & Mean & $\begin{array}{l}\text { Std. } \\
\text { Dev. }\end{array}$ \\
\hline $\begin{array}{l}\text { Timely preparation of financial } \\
\text { statements }\end{array}$ & 223 & $\begin{array}{l}1 \\
(0.4 \%)\end{array}$ & $\begin{array}{l}0 \\
(0.0 \%)\end{array}$ & $\begin{array}{l}222 \\
(99.6 \%)\end{array}$ & $\begin{array}{l}223 \\
(100 \%)\end{array}$ & 2.00 & 5.00 & 4.7623 & .45719 \\
\hline Adoption of cost efficiency mechanism & 223 & $\begin{array}{l}1 \\
(0.4)\end{array}$ & $\begin{array}{l}0 \\
(0.0 \%)\end{array}$ & $\begin{array}{l}222 \\
(99.6 \%)\end{array}$ & $\begin{array}{l}223 \\
(100 \%)\end{array}$ & 2.00 & 5.00 & 4.5695 & .52278 \\
\hline $\begin{array}{l}\text { Development of sound microfinance } \\
\text { practice with sustainable regulatory } \\
\text { framework }\end{array}$ & 223 & $(0.9 \%)$ & $(0.9 \%)$ & $\begin{array}{l}119 \\
(98.2 \%)\end{array}$ & $\begin{array}{l}223 \\
(100 \%)\end{array}$ & 2.00 & 5.00 & 4.6143 & .77443 \\
\hline Timely prosecution of fraudsters & 223 & $\begin{array}{l}1 \\
(0.4 \%)\end{array}$ & $\begin{array}{l}2 \\
(0.9 \%) \\
\end{array}$ & $\begin{array}{l}220 \\
(98.7 \%)\end{array}$ & $\begin{array}{l}223 \\
(100 \%)\end{array}$ & 2.00 & 5.00 & 4.3857 & .53201 \\
\hline $\begin{array}{l}\text { Introduction of more effective internal } \\
\text { control system }\end{array}$ & 223 & $\begin{array}{l}2 \\
(0.9 \%)\end{array}$ & $\begin{array}{l}0 \\
(0.0 \%) \\
\end{array}$ & $\begin{array}{l}221 \\
(99.1 \%)\end{array}$ & $\begin{array}{l}223 \\
(100 \%)\end{array}$ & 2.00 & 5.00 & 4.4619 & .55111 \\
\hline $\begin{array}{l}\text { Investing more on information } \\
\text { technology for enhancement of } \\
\text { operations }\end{array}$ & 223 & $\begin{array}{l}0 \\
(0.0 \%)\end{array}$ & $\begin{array}{l}1 \\
(0.4 \%)\end{array}$ & $\begin{array}{l}222 \\
(99.6 \%)\end{array}$ & $\begin{array}{l}223 \\
(100 \%)\end{array}$ & 3.00 & 5.00 & 4.5426 & .50824 \\
\hline $\begin{array}{l}\text { Improvement on the know-your- } \\
\text { customers (KYC) information } \\
\text { guidelines }\end{array}$ & 223 & $\begin{array}{l}1 \\
(0.4 \%)\end{array}$ & $\begin{array}{l}1 \\
(0.4 \%)\end{array}$ & $\begin{array}{l}221 \\
(99.2 \%)\end{array}$ & $\begin{array}{l}223 \\
(100 \%)\end{array}$ & 2.00 & 5.00 & 4.5381 & .53451 \\
\hline Standardisation of the quality, & 223 & 1 & 0 & 222 & 223 & 2.00 & 5.00 & 4.4619 & .52602 \\
\hline
\end{tabular}




\begin{tabular}{|c|c|c|c|c|c|c|c|c|c|}
\hline $\begin{array}{l}\text { experience, and qualifications of } \\
\text { management of microfinance banks }\end{array}$ & & $(0.4 \%)$ & $(0.0 \%)$ & $(99.6 \%)$ & $(100 \%)$ & & & & \\
\hline $\begin{array}{l}\text { Effective background check of staff } \\
\text { and customers }\end{array}$ & 223 & $\begin{array}{l}1 \\
(0.4 \%)\end{array}$ & $\begin{array}{l}0 \\
(0.0 \%)\end{array}$ & $\begin{array}{l}222 \\
(99.6 \%)\end{array}$ & $\begin{array}{l}223 \\
(100 \%)\end{array}$ & 2.00 & 5.00 & 4.4619 & .52602 \\
\hline $\begin{array}{l}\text { Timely investigation of any } \\
\text { undercapitalisation below the lower } \\
\text { limit }\end{array}$ & 223 & $\begin{array}{l}2 \\
(0.9 \%)\end{array}$ & $\begin{array}{l}5 \\
(2.2 \%)\end{array}$ & $\begin{array}{l}216 \\
(96.9 \%)\end{array}$ & $\begin{array}{l}223 \\
(100 \%)\end{array}$ & 1.00 & 5.00 & 4.4888 & .61411 \\
\hline $\begin{array}{l}\text { The need for government and other } \\
\text { stakeholders to inculcate sound } \\
\text { banking culture in management and } \\
\text { customers }\end{array}$ & 223 & $\begin{array}{l}3 \\
(1.3 \%)\end{array}$ & $\begin{array}{l}1 \\
(0.4 \%)\end{array}$ & $\begin{array}{l}219 \\
(98.3 \%)\end{array}$ & $\begin{array}{l}223 \\
(100 \%)\end{array}$ & 2.00 & 5.00 & 4.4574 & .58257 \\
\hline $\begin{array}{l}\text { Increase in revenue base through } \\
\text { products diversification }\end{array}$ & 223 & $\begin{array}{l}3 \\
(1.3 \%)\end{array}$ & $\begin{array}{l}3 \\
(1.3 \%)\end{array}$ & $\begin{array}{l}217 \\
(97.4 \%)\end{array}$ & $\begin{array}{l}223 \\
(100 \%)\end{array}$ & 2.00 & 5.00 & 4.4529 & .59750 \\
\hline $\begin{array}{l}\text { Creation of more awareness to the } \\
\text { poor and small businesses }\end{array}$ & 223 & $\begin{array}{l}4 \\
(1.8 \%)\end{array}$ & $\begin{array}{l}0 \\
(0.0 \%)\end{array}$ & $\begin{array}{l}219 \\
(98.2 \%)\end{array}$ & $\begin{array}{l}223 \\
(100 \%)\end{array}$ & 2.00 & 5.00 & 4.4395 & .59628 \\
\hline $\begin{array}{l}\text { The need for more workshops and } \\
\text { training programs for microfinance } \\
\text { staff }\end{array}$ & 223 & $\begin{array}{l}1 \\
(0.4 \%)\end{array}$ & $\begin{array}{l}1 \\
(0.4 \%)\end{array}$ & $\begin{array}{l}221 \\
(99.2 \%)\end{array}$ & $\begin{array}{l}223 \\
(100 \%)\end{array}$ & 2.00 & 5.00 & 4.6009 & .52625 \\
\hline $\begin{array}{l}\text { Building of investors' confidence } \\
\text { through government participation in } \\
\text { areas like provisions of security and } \\
\text { infrastructure }\end{array}$ & 223 & $\begin{array}{l}2 \\
(0.9 \%)\end{array}$ & $\begin{array}{l}0 \\
(0.0 \%)\end{array}$ & $\begin{array}{l}221 \\
(99.1 \%)\end{array}$ & $\begin{array}{l}223 \\
(100 \%)\end{array}$ & 2.00 & 5.00 & 4.5919 & .54469 \\
\hline $\begin{array}{l}\text { The need for a more proactive } \\
\text { corporate governance framework }\end{array}$ & 223 & $\begin{array}{l}3 \\
(1.3 \%)\end{array}$ & $\begin{array}{l}1 \\
(0.4 \%)\end{array}$ & $\begin{array}{l}219 \\
(98.3 \%)\end{array}$ & $\begin{array}{l}223 \\
(100 \%)\end{array}$ & 2.00 & 5.00 & 4.6637 & .56063 \\
\hline $\begin{array}{l}\text { Government should be more } \\
\text { consistent with policies }\end{array}$ & 223 & $\begin{array}{l}1 \\
(0.4 \%)\end{array}$ & $\begin{array}{l}1 \\
(0.4 \%)\end{array}$ & $\begin{array}{l}221 \\
(99.2 \%)\end{array}$ & $\begin{array}{l}223 \\
(100 \%)\end{array}$ & 2.00 & 5.00 & 4.6143 & .52348 \\
\hline $\begin{array}{l}\text { Appropriate tax incentives for MFBs to } \\
\text { enhance business growth }\end{array}$ & 223 & $\begin{array}{l}1 \\
(0.4 \%)\end{array}$ & $\begin{array}{l}0 \\
(0.0 \%)\end{array}$ & $\begin{array}{l}222 \\
(99.6 \%)\end{array}$ & $\begin{array}{l}223 \\
(100 \%)\end{array}$ & 2.00 & 5.00 & 4.7040 & .48614 \\
\hline $\begin{array}{l}\text { Government should establish a more } \\
\text { reliable data collection of small } \\
\text { businesses in need of funds }\end{array}$ & 223 & $\begin{array}{l}0 \\
(0.0 \%)\end{array}$ & $\begin{array}{l}3 \\
(1.3 \%)\end{array}$ & $\begin{array}{l}220 \\
(98.7 \%)\end{array}$ & $\begin{array}{l}223 \\
(100 \%)\end{array}$ & 3.00 & 5.00 & 4.5964 & .51847 \\
\hline $\begin{array}{l}\text { Effective monitoring of how loans } \\
\text { given to customers are utilised } \\
\text { through appropriate management- } \\
\text { customer forum }\end{array}$ & 223 & $\begin{array}{l}0 \\
(0.0 \%)\end{array}$ & $\begin{array}{l}3 \\
(1.3 \%)\end{array}$ & $\begin{array}{l}220 \\
(98.7 \%)\end{array}$ & $\begin{array}{l}223 \\
(100 \%)\end{array}$ & 3.00 & 5.00 & 4.7803 & .44637 \\
\hline Valid N (listwise) & 223 & & & & & & & & \\
\hline
\end{tabular}

\section{Conclusion and policy recommendations}

Microfinance banks in Nigeria were primarily set up to serve as the financial channel by which small business entrepreneurs and the poor of the society would have access to funding. It is then expected that the ability to actualise the objective would improve the services of MFBs, leading to the nation's economic growth. Scholars however opined that this has not been effectively achieved due to some challenging issues (Akande and Yinus, 2015; Alalade et al., 2013; Ehigiamusoe, 2005; Moruf, 2013; Sussan and Obamuyi, 2018; Andabai and Jessie, 2018). While studies have identified the problems confronting microfinance banks in Nigeria, these findings provide additional problems through empirical investigation that are relevant to both practitioners and policy makers. This study also establishes the mitigating factors that are germane to solving the identified problems. The results revealed that high operating and financial expenses; low revenue base; lack of effective corporate governance; lack of standard and uniformity in financial transactions; insiders' abuse; and ineffective monitoring of the allocated funds to ensure the utilisation as intended, among others are the problems affecting the growth of microfinance banks in Nigeria.

The findings also showed that timely preparation of financial statements; adoption of cost efficiency mechanism; investing more on information technology for enhancement of operations; standardisation of the quality, experience, and qualifications of management of microfinance; and effective background 
check of staff and customers, among others would mitigate the problems of MFBs in Nigeria. In view of these findings, this study therefore recommends the need for government to set up a body comprises of all stakeholders to ensure that the problems identified, and the mitigating factors are critically and objectively examined to adequately and timely address the issues raised. It is also recommended that the terms of reference for this body should be stressed upon to include procedural handling of ethical and professional breach without conflicting the roles of the existing regulatory bodies.

\section{Limitations of this study}

The use of Lagos State, one state out for the 36 states and Federal Capital Territory, Abuja, as the research area for a study about Nigeria is the limitation to this study

\section{Areas for further research}

For further study, researchers could use the number of the officially licensed microfinance banks and increase the number of the small entrepreneurs across the six geo-political zones in Nigeria to determine the population and the sample size. Further research could also seek for the opinion of the external auditors to microfinance banks for a more objective identification of the problems confronting these institutions.

\section{References}

Abubakar, L. S., Zainol, F. A. \& Abdullahi, M. S. (2015). Lingering challenges of Microfinance Institutions (MFIs) and the way forward. International Journal of Academic Research in Economics and Management, 4(3), 31-37. Doi: 10.6007/IJAREMS/v4-i3/1815

Ademoh, F. \& Zivkovic, J. (2017). Hindrances to microfinancing: A Nigerian case study. International Journal of Development and Economic Sustainability, 5(1), 45-60.

Ailemen, I. O., Asaolu, J. N. \& Areghna, I. (2016). Microfinance and poverty alleviation in South West Nigeria: Empirical Evidence. Journal of South African Business Research, 2016(2016), 1-19.

Akande, O. O. \& Yinus, O. (2015). An assessment of micro finance banks impact on entrepreneurship development in Nigeria. International Journal of Advances in Management and Economics, 4(3), 148-154.

Alalade, Y. S., Amusa, B. O. \& Adekunle, O. A. (2013). Microfinance bank as a catalyst for entrepreneurship development in Nigeria: Evidence from Ogun State. International Journal of Business and Social Science, 4(12), 286-303.

Aliu, N. A., Gakure, R. W. \& Orwa, G. (2015). Effects of Microfinance Bank's (MFBs) customer relationship management on services to Small and Medium Enterprises (SMEs) in Nigeria. International Journal of Advanced Studies in Business Strategies and Management, 3(1), 99-108.

Andabai, P. W. \& Jessie, I. C. (2018). Microfinance banks' credit and the growth of Small and Medium Scale Businesses (SMBS) in Nigeria (1990-2016): Investigating the nexus. Journal of Economics and Sustainable Development, 9(6), 28-33.

Ashamu, S. O. (2014). The impact of micro-finance on small scale business in Nigeria. Journal of Policy and Development Studies, 9(1), 179-193.

Bakare, M. A. (2019). Microfinance credits and growth of business firms in Nigeria. International Journal of Innovation and Research in Educational Sciences, 6(6), 782-790.

Dutse, A. Y., Ningi, S. I. \& Abubakar, S. (2013). Technopreneurship and enterprise growth in Nigeria: An exploration into the latent role microfinance banks. IOSR Journal of Business and Management (IOSR-JBM), 12(2), 25-32.

Ehigiamusoe, G. (2005). Tested institutional practices for efficient microfinance services delivery. A paper presented at the launching of microfinance policy, regulation and supervisory framework for Nigeria and the national seminar to mark the United Nations International Year of Microcredit (IYMC), Abuja.

Khan, B. (2020). Microfinance banks and its impact on small and medium scale enterprises in Nigeria. World Scientific News, 141, 151-131.

Murad, A. B. \& Idewele, I. S. O. (2017). International Journal of Development and Management Review (INJODEMAR), 12(1), 1-17.

Nwachukwu, C., Chladkova, H, \& Zufan, P. (2017). Empirical assessment of microfinance banks in Nigeria using EFQM excellence model. International Journal for Quality Research, 11(2), 279-294. Doi - 10.18421/IJQR11.0203

Nwude, E. C. \& Anyalechi, K. C. (2018). The impact of microfinance on rural economic growth: The Nigerian experience. International Journal of Economics and Financial Issues, 8(4), 27-31.

Obadeyi, J. A. (2015). Microfinance banking and development of small business in emerging economy: Nigerian Approach. IOSR Journal of Economics and Finance (IOSR-JEF), 6(2:1), 50-60. Doi: 10.9790/5933-06215060. 
Obasi, N. J., Chukwuka, O. I. \& Akwawa, U. A. (2014). Impact of microfinance lending on economic growth of third world nations: Study of Nigeria. International Journal of Business, Economics and Management, 1(8), 201-215.

Obokoh, L. O., Monday, J. U. \& Ojiako, U. (2016). Microfinance banks and small and medium sized Enterprises access to finance: The Nigerian experience. Banks and Bank Systems, 11(4), 111-121.

Reusser, K \& Stebler, R. (1997). Every word problem has a solution - the social rationality of mathematical modelling in schools. Learning and Instruction, 7(4), 309-327.

Sussan, M. U. \& Obamuyi, T. (2018). The impact of microfinance banks on entrepreneurship development in Nigeria. Journal of Business and Economic Development, 3(2), 51-61. Doi: 10.11648/j.jbed.20180302.13

Taiwo, J. N., Onasanya, A. Y., Agwu, M. E. \& Benson, K. N. (2016). The role of microfinance institutions in financing small businesses. Journal of Internet Banking and Commerce, 21(1), 1-20. 